\title{
Research Article \\ SYNTHESIS, CHARACTERIZATION AND ANTIMICROBIAL STUDIES OF NOVEL ORGANOBISMUTH(III) COMPLEXES
}

\author{
GUPTA PRAMILA, RANI PREETI AND RAVI KANT * \\ Department of Chemistry, Mewar University, Chittorgarh, 312901, Rajasthan, India \\ *Corresponding Author: Email- drravikant78@gmail.com
}

Received: March 21, 2018; Revised: March 24, 2018; Accepted: March 25, 2018; Published: March 30, 2018

\begin{abstract}
The Present Manuscript deals the synthesis of some novel organobismuth(III)aryloxyacetates followed by their characterization by melting points, elemental analysis, U.V., I.R and NMR spectral analysis to confirm their structures and geometry. The compounds were also screened for their antibacterial and antifungal efficacy against pathogenic bacterial and fungal strains. It was found that these compounds exhibit higher activity than the standard drug for bactericidal and fungicidal activity.
\end{abstract}

Keywords- Organobismuth, aryloxyacetates, antibacterial, antifungal

Citation: Gupta Pramila, et al., (2018) Synthesis, Characterization and Antimicrobial studies of Novel Organobismuth(III) Complexes. International Journal of Microbiology Research, ISSN: 0975-5276 \& E-ISSN: 0975-9174, Volume 10, Issue 3, pp.-1086-1089. DOl: http://dx.doi.org/10.9735/0975-5276.10.3.1086-1089

Copyright: Copyright@2018 Gupta Pramila, et al., This is an open-access article distributed under the terms of the Creative Commons Attribution License, which permits unrestricted use, distribution and reproduction in any medium, provided the original author and source are credited.

\section{Introduction}

The acetates in organic derivatives of group 15 elements could behave as monodentate, bidentate or as bridging ligands depending on the oxidation state $(+3$ or +5$)$; physical state of the compound (solid or solution) and the various substituents present on the acetate group itself [1-10]. It has been found that major influences in determining mode of bonding, geometry and stability of the acetate system in general are the absence of ligand atom trans to an organic group; the preservation of the preferred angle of $120^{\circ}$ at bounded oxygen atom and maximizing of secondary bonding via a bridging for acetate. Another important group of ligand which has not attracted much attention, but closely resembles to carboxylates is aryloxyacetates. However unlike acetate, aryloxyacetates has one extra donor site i.e. Ax-0-, in addition to the $-\mathrm{C}=0$ functionality. It is noteworthy that despite such a great variety of structural possibilities, as discussed above exhibited by organometallic carboxylates and by the variety of metals for which such derivatives have been synthesized, corresponding aryloxyacetates are mainly confirmed to transition metal derivatives [11] with an occasional reference on organotin and organoantimony [12] derivatives. A perusal of the literature further reveals that the complexes of aryloxyacetic acids in case of organotin possess intramolecular 0 --->Sn coordination; particularly for alkyl tin derivatives and the compounds are monomeric in solid state. In sharp contrast to this triaryltin derivatives having pentaco-ordination, were found to be polymeric with bridging carboxylic group [1319]. On the basis of ultraviolet and infrared spectra it has been concluded that aryloxyacetate behave as monodentate ligand towards bismuth. The principal objective of this work was to synthesize and characterized biomedicinaly unreported organobismuth (III) aryloxyacetate derivatives; to investigate the role of ethereal oxygen of aryloxyacetate group i.e. whether it participates in bonding or not and thus raising the coordination number of bismuth(III) beyond three; to ascertain the mode of bonding of aryloxyacetate group towards bismuth i.e. whether the acetate group (s) acts as monodentate or bidentate group or as a both; to compare and contrast the behavior of aryloxyacetate ligand with that of acetate and to evaluate the newly synthesized organobismuth compounds for their biomedicinal importance against various pathogenic diseases.

\section{Experimental}

The diorganobismuth (III) chloride, $\mathrm{R}_{2} \mathrm{BiCl}$ and organobismuth (III) dichloride, $\mathrm{RBiCl}_{2}$ was prepared by the redistribution reaction [20]. The syntheses of some representative compounds are as follows.

\section{Reaction of $\left(\mathrm{C}_{6} \mathrm{H}_{5}\right)_{2} \mathrm{Bi}(\mathrm{III}) \mathrm{Cl}$ with $\left(\mathrm{C}_{6} \mathrm{H}_{5} \mathrm{OCH}_{2} \mathrm{COOH}\right)$ (1)}

In the stirring solution of diphenylbismuth(III)chloride $(0.398 \mathrm{gm} ; 1 \mathrm{mmol})$, phenoxyacetic acid $(0.152 \mathrm{gm} ; 1 \mathrm{mmol})$ was added in presence of triethylamine (1 $\mathrm{ml}$ ) in benzene and was stirred in anhydrous oxygen free, nitrogen conditions for $6 h$, followed by refluxing for $2 \mathrm{~h}$ to ensure completion of the reaction. A flocculent white precipitate of $\mathrm{Et}_{3} \mathrm{~N} . \mathrm{HCl}\left(\mathrm{M} . \mathrm{P} .240^{\circ} \mathrm{C}\right.$ ) was formed which was filtered off. The filtrate on concentration gave a light brown solid which was recrystallised by petroleum ether $\left(40^{\circ}-60^{\circ} \mathrm{C}\right)$.

\section{Reaction of $\left(\mathrm{C}_{6} \mathrm{H}_{5}\right)_{2} \mathrm{Bi}(\mathrm{III}) \mathrm{Cl}$ with $\left(p-\mathrm{CH}_{3} \mathrm{C}_{6} \mathrm{H}_{4} \mathrm{OC} \mathrm{CH}_{2} \mathrm{COOH}\right)$ (2)}

In the stirring solution of diphenylbismuth(III)chloride $(0.398 \mathrm{gm} ; 1 \mathrm{mmol})$, p-methyl phenoxyacetic acid $(0.166 \mathrm{gm} ; 1 \mathrm{mmol})$ was added in presence of triethylamine $(1 \mathrm{ml})$ in benzene and was stirred in anhydrous oxygen free, nitrogen atmosphere for $6 h$, followed by refluxing for $2 h$ to ensure completion of the reaction. A flocculent white precipitate of $\mathrm{Et}_{3} \mathrm{~N} . \mathrm{HCl}$ (M.P. $240^{\circ} \mathrm{C}$ ) was formed which was filtered off. The filtrate on concentration afforded a light brown solid which was recrystallised by petroleum ether $\left(40^{\circ}-60^{\circ} \mathrm{C}\right)$.

\section{Reaction of $\left(\mathrm{C}_{6} \mathrm{H}_{5}\right)_{2} \mathrm{Bi}(\mathrm{III}) \mathrm{Cl}$ with $\left(\mathrm{p}-\mathrm{ClC}_{6} \mathrm{H}_{4} \mathrm{OCH}_{2} \mathrm{COOH}\right)(3)$}

In the stirring solution of diphenylbismuth(III)chloride $(0.398 \mathrm{gm} ; 1 \mathrm{mmol}), p$-chloro phenoxyacetic acid $(0.186 \mathrm{gm} ; 1 \mathrm{mmol})$ was added in presence of triethylamine $(1 \mathrm{ml})$ in benzene and was stirred in anhydrous oxygen free, nitrogen atmosphere for $6 h$, followed by refluxing for $2 h$ to ensure completion of the reaction. A white 
colour precipitate of Et ${ }_{3} \mathrm{~N} . \mathrm{HCl}\left(\mathrm{M} . \mathrm{P} .240^{\circ} \mathrm{C}\right)$ was formed which was filtered off and the filtrate on concentration in vaccum afforded a light brown solid which was recrystallised by petroleum ether $\left(40^{\circ}-60^{\circ} \mathrm{C}\right)$.

\section{Reaction of $\left(\mathrm{C}_{6} \mathrm{~F}_{5}\right)_{2} \mathrm{Bi}(\mathrm{III}) \mathrm{Cl}$ with $\left(\mathrm{C}_{6} \mathrm{H}_{5} \mathrm{OCH}_{2} \mathrm{COOH}\right)(4)$}

In the stirring solution of bis(pentafluorophenyl) bismuth(III)chloride $(0.578 \mathrm{gm}$; $1 \mathrm{mmol})$, phenoxyacetic acid $(0.152 \mathrm{gm} ; 1 \mathrm{mmol})$ was added in presence of triethylamine (1 $\mathrm{ml})$ in benzene and was stirred in anhydrous oxygen free, nitrogen conditions for $6 h$, followed by refluxing for $2 h$ to ensure completion of the reaction. A flocculent white precipitate of $\mathrm{Et}_{3} \mathrm{~N} . \mathrm{HCl}$ (M.P. $240^{\circ} \mathrm{C}$ ) was formed which was filtered off. The filtrate on concentration gave a light brown solid which was recrystallised by petroleum ether $\left(40^{\circ}-60^{\circ} \mathrm{C}\right)$.

\section{Reaction of $\left(\mathrm{C}_{6} \mathrm{~F}_{5}\right)_{2} \mathrm{Bi}(\mathrm{III}) \mathrm{Cl}$ with $\left(\mathrm{p}-\mathrm{CH}_{3} \mathrm{C}_{6} \mathrm{H}_{4} \mathrm{OCH}_{2} \mathrm{COOH}\right)(5)$}

In the stirring solution of bis(pentafluorophenyl) bismuth (III) chloride $(0.578 \mathrm{gm}$; $1 \mathrm{mmol})$, p-methyl phenoxyacetic acid $(0.166 \mathrm{gm} ; 1 \mathrm{mmol})$ was added in presence of triethylamine $(1 \mathrm{ml})$ in benzene and was stirred in anhydrous oxygen free, nitrogen conditions for $6 h$, followed by refluxing for $2 h$ to ensure completion of the reaction. A flocculent white precipitate of $\mathrm{Et}_{3} \mathrm{~N} . \mathrm{HCl}$ (M.P. $240^{\circ} \mathrm{C}$ ) was formed which was filtered off. The filtrate on concentration afforded a light brown solid which was recrystallised by petroleum ether $\left(40^{\circ}-60^{\circ} \mathrm{C}\right)$.

\section{Reaction of $\left(\mathrm{C}_{6} \mathrm{~F}_{5}\right)_{2} \mathrm{Bi}(\mathrm{III}) \mathrm{Cl}$ with $\left(p-\mathrm{ClC}_{6} \mathrm{H}_{4} \mathrm{OCH}_{2} \mathrm{COOH}\right)(6)$}

In the stirring solution of bis (pentafluorophenyl) bismuth(III)chloride (0.578gm; $1 \mathrm{mmol}), p$-chloro phenoxyacetic acid $(0.186 \mathrm{gm} ; 1 \mathrm{mmol})$ was added in presence of triethylamine $(1 \mathrm{ml})$ in benzene and was stirred in anhydrous oxygen free, nitrogen conditions for $6 h$, followed by refluxing for $2 \mathrm{~h}$ to ensure completion of the reaction. A white colour precipitate of $\mathrm{Et}_{3} \mathrm{~N} . \mathrm{HCl}\left(\mathrm{M} . \mathrm{P} .240^{\circ} \mathrm{C}\right.$ ) was formed which was filtered off and the filtrate on concentration in vaccum afforded a light brown solid which was recrystallised by petroleum ether $\left(40^{\circ}-60^{\circ} \mathrm{C}\right)$.

\section{Reaction of $\left(p-\mathrm{FC}_{6} \mathrm{H}_{4}\right)_{2} \mathrm{Bi}(\mathrm{III}) \mathrm{Cl}$ with $\left(\mathrm{C}_{6} \mathrm{H}_{5} \mathrm{OCH} \mathrm{CH}_{2} \mathrm{COOH}\right)(7)$}

In the stirring solution of bis(p-fluorophenyl)bismuth(III)chloride $(0.434 \mathrm{gm} ; 1 \mathrm{mmol})$, phenoxyacetic acid $(0.152 \mathrm{gm} ; 1 \mathrm{mmol})$ was added in presence of triethylamine (1 $\mathrm{ml}$ ) in benzene and was stirred in anhydrous oxygen free, nitrogen conditions for $6 h$, followed by refluxing for $2 \mathrm{~h}$ to ensure completion of the reaction. A flocculent white precipitate of $\mathrm{Et}_{3} \mathrm{~N} . \mathrm{HCl}\left(\mathrm{M} . \mathrm{P} .240^{\circ} \mathrm{C}\right.$ ) was formed which was filtered off. The filtrate on concentration gave a light brown solid which was recrystallised by petroleum ether $\left(40^{\circ}-60^{\circ} \mathrm{C}\right)$.

\section{Reaction of $\left(p-\mathrm{FC}_{6} \mathrm{H}_{4}\right)_{2} \mathrm{Bi}(\mathrm{III}) \mathrm{Cl}$ with $\left(p-\mathrm{CH}_{3} \mathrm{C}_{6} \mathrm{H}_{4} \mathrm{OCH} \mathrm{CH}_{2} \mathrm{COOH}\right)$ (8)}

In the stirring solution of bis( $p$-fluorophenyl)bismuth(III)chloride $(0.434 \mathrm{gm} ; 1 \mathrm{mmol})$, p-methyl phenoxyacetic acid $(0.166 \mathrm{gm} ; 1 \mathrm{mmol})$ was added in presence of triethylamine $(1 \mathrm{ml})$ in benzene and was stirred in anhydrous oxygen free, nitrogen conditions for $6 h$, followed by refluxing for $2 \mathrm{~h}$ to ensure completion of the reaction. A flocculent white precipitate of $\mathrm{Et}_{3} \mathrm{~N} . \mathrm{HCl}$ (M.P. $240^{\circ} \mathrm{C}$ ) was formed which was filtered off. The filtrate on concentration afforded a light brown solid which was recrystallised by petroleum ether $\left(40^{\circ}-60^{\circ} \mathrm{C}\right)$.

\section{Reaction of $\left(p-\mathrm{FC}_{6} \mathrm{H}_{4}\right)_{2} \mathrm{Bi}(\mathrm{III}) \mathrm{Cl}$ with $\left(p-\mathrm{ClC}_{6} \mathrm{H}_{4} \mathrm{OCH}_{2} \mathrm{COOH}\right)$ (9)}

In the stirring solution of bis(p-fluorophenyl)bismuth(III)chloride $(0.434 \mathrm{gm} ; 1 \mathrm{mmol})$, p-chloro phenoxyacetic acid $(0.186 \mathrm{gm} ; 1 \mathrm{mmol})$ was added in presence of triethylamine $(1 \mathrm{ml})$ in benzene and was stirred in anhydrous oxygen free, nitrogen conditions for $6 h$, followed by refluxing for $2 h$ to ensure completion of the reaction. A white colour precipitate of $\mathrm{Et}_{3} \mathrm{~N} . \mathrm{HCl}\left(\mathrm{M} . \mathrm{P} .240^{\circ} \mathrm{C}\right.$ ) was formed which was filtered off and the filtrate on concentration in vacuum afforded a light brown solid which was recrystallised by petroleum ether $\left(40^{\circ}-60^{\circ} \mathrm{C}\right)$.

\section{Antibacterial activity}

The antibacterial activity of these organobismuth (III) compounds was determined by disc diffusion method [21]. In this technique, the filter paper (Whatman No. 1) sterile discs of $5 \mathrm{~mm}$ diameter, impregnated with the test compounds $(10 \mu \mathrm{g} / \mathrm{ml}$ of ethanol) were placed on the nutrient agar plate at $37^{\circ} \mathrm{C}$ for $24 \mathrm{hrs}$. The inhibition zones around the dried impregnated discs were measured after $24 \mathrm{hrs}$. The activity was classified as 'highly active' (diameter $>14 \mathrm{~mm}$ ); "moderately active" (diameter $=10-14 \mathrm{~mm}$ ) and 'slightly active' (diameter $=6-10)$. The diameter less than $6 \mathrm{~mm}$ was regarded as inactive.

\section{Antifungal activity}

The antifungal activity of these compounds was tested by agar diffusion method [22] using two concentrations of the test compound, viz., 50 and $100 \mu \mathrm{g} / \mathrm{ml}$; against Aspergillus flavus and Aspergillus niger. The one $\mathrm{ml}$ of each organobismuth compound was poured into a petri dish having about $20-25 \mathrm{ml}$ of molten potato dextrose agar medium. As the medium gets solidify, petri dishes were inoculated separately with the fungal isolates and kept at $26{ }^{\circ} \mathrm{C}$ for $96 \mathrm{hrs}$ in incubator. All the values (\% inhibition) were recorded after $96 \mathrm{hrs}$. The \% inhibition of these compounds was calculated by using following mathematical equation.

$$
\text { Percent (\%) Inhibition = C-T/C X } 100
$$

Here: $\mathrm{C}=$ Diameter of fungus in control.

$\mathrm{T}=$ Diameter of fungus in test compound.

\section{Results and Discussion}

All the reactions were conducted at room temperature and the products were recrystallised from petroleum ether $\left(40-60^{\circ} \mathrm{C}\right)$ or in benzene. The complexes are off-white to light brown solids and obtained as a sticky mass which on treatment with sodium in dry benzene gets solidified and subsequently crystallized with benzene/pet-ether. The complexes are fairly stable on air and moisture and have sharp melting point. There is no regular trend of the melting point of the complexes and they melt without decomposition. Complexes are also soluble in chloroform and acetonitrile. They can be stored at room temperature without decomposition for several weeks. The consistency in melting points after repeated crystallization as well as TLC run in chloroform hexane mixture (1:1) with the observation of a single spot excluded the presence of mixture of reactants. The molar conductance value of 10-3 $\mathrm{M}$ solution of these compounds were recorded in methanol and found in the range of $15-250 \mathrm{hm}^{-1} \mathrm{~mole}^{-1} \mathrm{~cm}^{2}$ indicating the absence of ionic species in solution. The complexes were found to be monomeric in nitrobenzene.

\section{IR Spectra}

As expected infrared absorptions inherent to phenyland fluorophenyl groups bound to bismuth have no difference appreciably and hence not discussed. The Infrared absorptions having diagnostic value for organobismuth aryloxyacetates, related to the ligand, have been identified which on preliminary stage indicates the mode of bonding with aryloxy ligand. The characteristic $\mathrm{v}(\mathrm{OH})$ absorption band of ligands which appeared around $3400 \mathrm{~cm}^{-1}$ in the free ligand, was found missing in the newly synthesized complexes. A medium strong intensity band appearing at $1690-1700 \mathrm{~cm}^{-1}$ can confidently be assigned to vasy (OCO) mode while comparatively weaker band in the range $1380-1400 \mathrm{~cm}^{-1}$ can be attributed to Vsym (OCO) band. The deformation mode as a medium intensity band was found in the range 780-815 $\mathrm{cm}^{-1}$. The absorption associated with the bismuth-oxygen appears in the range between $400-430 \mathrm{~cm}^{-1}$ and the absorption due to bismuth-carbon corresponding to $y$-mode occurs in the range $450-470 \mathrm{~cm}^{-1}$. These values clearly indicated the formation of organobismuth (III) aryloxyacetates. The comparison of IR spectra of the compounds with those of respective ligands in solid and solution states did not show any significant shift in $\mathrm{V}_{\text {asy }}(\mathrm{C}=0)$, $\mathrm{V}_{\text {sym }}(\mathrm{C}-\mathrm{O})$ and $\mathrm{v}(\mathrm{C}-\mathrm{O}-\mathrm{C})$ deformation bands which in turn showed the lack of coordination with bismuth through $-\mathrm{C}=0$ or $\mathrm{C}-\mathrm{O}-\mathrm{Ar}$ center of the ligand. Since the separation observed in the present compounds is fairly large $\left(2300 \mathrm{~cm}^{-1}\right)$, monomolecular constitution seems to be most plausible where bismuth would be have a coordination number three. This observation is clearly sharp contrast to organotin complexes of aryloxyacetates which have been found to be polymeric involving carboxylic bridges. In addition to this intermolecular interaction involving the ethereal oxygen has also been demonstrated in some cases particularly.

\section{${ }^{1}$ HNMR Spectra}

${ }^{1} \mathrm{H}$ NMR spectra of these compounds was recorded in $\mathrm{CDCl}_{3}$ using TMS as an 
internal reference at $25^{\circ} \mathrm{C}$. The disappearance of $\mathrm{OH}$ proton signals (89.1 ppm) present in the ligand clearly indicates the formation of aryloxyacetate derivatives. The appearance of singlet for $-\mathrm{CH}_{3}$ protons at $84.85 \mathrm{ppm}$ showed the ligand is in one plane. The pheny1 protons for both the derivatives appear as multiplets in the range $87.80-7.20 \mathrm{ppm}$.

\section{UV Spectra}

The electronic spectra obtained for representative compounds were recorded in chloroform in the range $200-400 \mathrm{~nm}$. The UV absorption due to COO group appears at $274 \pm 6$ and $294 \pm 2$ are due to aryloxy moieties. Since there was no significant change in absorption peaks of the ligands indicates that $-\mathrm{C}=0$ and $-\mathrm{C}$ 0 -Ar centre of aryloxyacetates are not coordinated to bismuth in any of the compounds. This also lends to support to the fact that aryloxyacetates behave as monodentate ligand towards bismuth in +3 oxidation state.

\begin{tabular}{|c|c|c|c|c|c|c|}
\hline \multicolumn{7}{|c|}{ Table-1 Physicochemical studies of organobismuth (III) aryloxyacetates } \\
\hline S.N. & Compounds & Formula & M.P. $\left({ }^{\circ} \mathrm{C}\right)$ & Color & Yield (\%) & Solvent \\
\hline 1 & $\left(\mathrm{C}_{6} \mathrm{H}_{5}\right)_{2} \mathrm{Bi}\left(\mathrm{OOC} . \mathrm{CH}_{2} \mathrm{OC}_{6} \mathrm{H}_{5}\right)$ & $\mathrm{C}_{20} \mathrm{H}_{17} \mathrm{O}_{3} \mathrm{Bi}$ & 190 & Light Brown & 60 & Pet-ether \\
\hline 2 & $\left(\mathrm{C}_{6} \mathrm{H}_{5}\right)_{2} \mathrm{Bi}\left(\mathrm{OOC} . \mathrm{CH}_{2} \mathrm{OC}_{6} \mathrm{H}_{4} \mathrm{CH}_{3}\right)$ & $\mathrm{C}_{21} \mathrm{H}_{19} \mathrm{O}_{3} \mathrm{Bi}$ & 156 & Light Brown & 75 & Pet-ether \\
\hline 3 & $\left(\mathrm{C}_{6} \mathrm{H}_{5}\right)_{2} \mathrm{Bi}\left(\mathrm{OOC} \mathrm{CH}_{2} \mathrm{OC}_{6} \mathrm{H}_{4} \mathrm{Cl}\right)$ & $\mathrm{C}_{20} \mathrm{H}_{16} \mathrm{O}_{3} \mathrm{ClBi}$ & 214 & Light Brown & 70 & Pet-ether \\
\hline 4 & $\left(\mathrm{C}_{6} \mathrm{~F}_{5}\right)_{2} \mathrm{Bi}\left(\mathrm{OOC}_{2} \mathrm{CH}_{2} \mathrm{OC}_{6} \mathrm{H}_{5}\right)$ & $\mathrm{C}_{20} \mathrm{~F}_{10} \mathrm{H}_{7} \mathrm{O}_{3} \mathrm{Bi}$ & 184 & Light Brown & 65 & Pet-ether \\
\hline 5 & $\left(\mathrm{C}_{6} \mathrm{~F}_{5}\right)_{2} \mathrm{Bi}\left(\mathrm{OOC} . \mathrm{CH}_{2} \mathrm{OC}_{6} \mathrm{H}_{4} \cdot \mathrm{CH}_{3}\right)$ & $\mathrm{C}_{21} \mathrm{~F}_{10} \mathrm{H}_{9} \mathrm{O}_{3} \mathrm{Bi}$ & 176 & Light Brown & 60 & Pet-ether \\
\hline 6 & $\left(\mathrm{C}_{6} \mathrm{~F}_{5}\right)_{2} \mathrm{~B}\left(\mathrm{OOC} . \mathrm{CH}_{2} \mathrm{OC}_{6} \mathrm{H}_{4} \mathrm{Cl}\right)$ & $\mathrm{C}_{20} \mathrm{~F}_{10} \mathrm{H}_{6} \mathrm{O}_{3} \mathrm{ClBi}$ & 204 & Light Brown & 60 & Pet-ether \\
\hline 7 & $\left(p-\mathrm{FC}_{6} \mathrm{H}_{4}\right)_{2} \mathrm{Bi}\left(\mathrm{OOC}_{-} \mathrm{CH}_{2} \mathrm{OC}_{6} \mathrm{H}_{5}\right)$ & $\mathrm{C}_{20} \mathrm{~F}_{2} \mathrm{H}_{15} \mathrm{O}_{3} \mathrm{Bi}$ & 192 & Light Brown & 60 & Pet-ether \\
\hline 8 & $\left(p-\mathrm{FC}_{6} \mathrm{H}_{4}\right)_{2} \mathrm{Bi}\left(\mathrm{OOC} . \mathrm{CH}_{2} \mathrm{OC}_{6} \mathrm{H}_{4} . \mathrm{CH}_{3}\right)$ & $\mathrm{C}_{21} \mathrm{~F}_{2} \mathrm{H}_{17} \mathrm{O}_{3} \mathrm{Bi}$ & 182 & Light Brown & 75 & Pet-ether \\
\hline 9 & $\left(p-\mathrm{FC}_{6} \mathrm{H}_{4}\right)_{2} \mathrm{Bi}\left(\mathrm{OOC}_{\mathrm{C}} \mathrm{CH}_{2} \mathrm{OC}_{6} \mathrm{H}_{4} \mathrm{Cl}\right)$ & $\mathrm{C}_{20} \mathrm{~F}_{2} \mathrm{H}_{14} \mathrm{O}_{3} \mathrm{ClBi}$ & 198 & Light Brown & 70 & Pet-ether \\
\hline
\end{tabular}

\begin{tabular}{|c|c|c|c|c|c|c|c|}
\hline \multirow{3}{*}{ S.N. } & \multicolumn{7}{|c|}{ Table-2 Analytical studies organobismuth (III) aryloxyacetates } \\
\hline & \multirow{2}{*}{$\begin{array}{c}\text { Compounds } \\
\text { Formula }\end{array}$} & \multirow{2}{*}{$\begin{array}{c}\text { Formula } \\
\text { weight }\end{array}$} & \multicolumn{2}{|c|}{ Elemental Analysis } & \multicolumn{3}{|c|}{ IR Absorption frequencies } \\
\hline & & & $\mathrm{C}(\%)$ & $\mathrm{H}(\%)$ & $\mathrm{V}_{\text {asy }}(\mathrm{OCO})$ & $V_{\text {sym }}(\mathrm{OCO})$ & $\mathrm{v}(\mathrm{Bi}-\mathrm{C})$ \\
\hline 1 & $\mathrm{C}_{20} \mathrm{H}_{17} \mathrm{O}_{3} \mathrm{Bi}$ & 514 & 46.69 & 3.30 & 1695 & 1395 & 411 \\
\hline 2 & $\mathrm{C}_{21} \mathrm{H}_{19} \mathrm{O}_{3} \mathrm{Bi}$ & 528 & 47.73 & 3.60 & 1694 & 1385 & 415 \\
\hline 3 & $\mathrm{C}_{20} \mathrm{H}_{16} \mathrm{O}_{3} \mathrm{ClBi}$ & 548.5 & 43.76 & 2.92 & 1694 & 1387 & 417 \\
\hline 4 & $\mathrm{C}_{20} \mathrm{~F}_{10} \mathrm{H}_{7} \mathrm{O}_{3} \mathrm{Bi}$ & 694 & 34.58 & 1.01 & 1696 & 1390 & 419 \\
\hline 5 & $\mathrm{C}_{21} \mathrm{~F}_{10} \mathrm{H}_{9} \mathrm{O}_{3} \mathrm{Bi}$ & 708 & 35.59 & 1.27 & 1700 & 1397 & 410 \\
\hline 6 & $\mathrm{C}_{20} \mathrm{~F}_{10} \mathrm{H}_{6} \mathrm{O}_{3} \mathrm{ClBi}$ & 728.5 & 32.94 & 0.82 & 1697 & 1400 & 425 \\
\hline 7 & $\mathrm{C}_{20} \mathrm{~F}_{2} \mathrm{H}_{15} \mathrm{O}_{3} \mathrm{Bi}$ & 550 & 43.64 & 2.72 & 1692 & 1406 & 428 \\
\hline 8 & $\mathrm{C}_{21} \mathrm{~F}_{2} \mathrm{H}_{17} \mathrm{O}_{3} \mathrm{Bi}$ & 564 & 44.68 & 3.01 & 1688 & 1394 & 422 \\
\hline 9 & $\mathrm{C}_{20} \mathrm{~F}_{2} \mathrm{H}_{14} \mathrm{O}_{3} \mathrm{ClBi}$ & 584.5 & 41.06 & 2.39 & 1694 & 1408 & 431 \\
\hline
\end{tabular}

Table-3 Anti-bacterial activity of organobismuth (III) aryloxyacetates

\begin{tabular}{|c|c|c|c|c|c|}
\hline S. N. & Compounds & Control & Pseudomonas aeruginosa & Staphylococcus aureus & Klebsiela pneumoniae \\
\hline 1 & $\left(\mathrm{C}_{6} \mathrm{H}_{5}\right)_{2} \mathrm{Bi}\left(\mathrm{OOC} . \mathrm{CH}_{2} \mathrm{OC}_{6} \mathrm{H}_{5}\right)$ & - & $++t$ & +++ & t+ \\
\hline 2 & $\left(\mathrm{C}_{6} \mathrm{H}_{5}\right)_{2} \mathrm{Bi}\left(\mathrm{OOC} \mathrm{CH}_{2} \mathrm{OC}_{6} \mathrm{H}_{4} \cdot \mathrm{CH}_{3}\right)$ & - & ++ & ++ & ++ \\
\hline 3 & $\left(\mathrm{C}_{6} \mathrm{H}_{5}\right)_{2} \mathrm{Bi}\left(\mathrm{OOC} . \mathrm{CH}_{2} \mathrm{OC}_{6} \mathrm{H}_{4} . \mathrm{Cl}\right)$ & - & t+t & $+t$ & t+ \\
\hline 4 & $\left(\mathrm{C}_{6} \mathrm{~F}_{5}\right)_{2} \mathrm{Bi}\left(\mathrm{OOC} \cdot \mathrm{CH}_{2} \mathrm{OC}_{6} \mathrm{H}_{5}\right)$ & - & ++ & ++ & ++ \\
\hline 5 & $\left(\mathrm{C}_{6} \mathrm{~F}_{5}\right)_{2} \mathrm{Bi}\left(\mathrm{OOC} . \mathrm{CH}_{2} \mathrm{OC}_{6} \mathrm{H}_{4} \cdot \mathrm{CH}_{3}\right)$ & - & ++ & ++ & +++ \\
\hline 6 & $\left(\mathrm{C}_{6} \mathrm{~F}_{5}\right)_{2} \mathrm{Bi}\left(\mathrm{OOC} . \mathrm{CH}_{2} \mathrm{OC}_{6} \mathrm{H}_{4} . \mathrm{Cl}\right)$ & - & +++ & ++ & ++ \\
\hline 7 & $\left(p-\mathrm{FC}_{6} \mathrm{H}_{4}\right)_{2} \mathrm{Bi}\left(\mathrm{OOC} \mathrm{CH}_{2} \mathrm{OC}_{6} \mathrm{H}_{5}\right)$ & - & ++ & t+ & ++ \\
\hline 8 & $\left(p-\mathrm{FC}_{6} \mathrm{H}_{4}\right)_{2} \mathrm{Bi}\left(\mathrm{OOC} \cdot \mathrm{CH}_{2} \mathrm{OC}_{6} \mathrm{H}_{4} \cdot \mathrm{CH}_{3}\right)$ & - & ++ & ++ & $t+t$ \\
\hline 9 & $\left(p-\mathrm{FC}_{6} \mathrm{H}_{4}\right)_{2} \mathrm{Bi}\left(\mathrm{OOC} . \mathrm{CH}_{2} \mathrm{OC}_{6} \mathrm{H}_{4} \mathrm{Cl}\right)$ & - & +++ & +++ & ++ \\
\hline
\end{tabular}

\begin{tabular}{|c|c|c|c|c|c|}
\hline S.N. & Compounds & $\begin{array}{c}\text { Aspergillus flavus } \\
\text { Col. Dia. }(\mathrm{mm})\end{array}$ & $\%$ Inhibition & $\begin{array}{l}\text { Aspergillus niger } \\
\text { Col. Dia. }(\mathrm{mm})\end{array}$ & $\begin{array}{c}\% \\
\text { Inhibitior }\end{array}$ \\
\hline 1 & $\left(\mathrm{C}_{6} \mathrm{H}_{5}\right)_{2} \mathrm{Bi}\left(\mathrm{OOC} . \mathrm{CH}_{2} \mathrm{OC}_{6} \mathrm{H}_{5}\right)$ & 0.7 & 76.6 & 0.6 & 70.0 \\
\hline 2 & $\left(\mathrm{C}_{6} \mathrm{H}_{5}\right)_{2} \mathrm{Bi}\left(\mathrm{OOC}_{\mathrm{CH}} \mathrm{CH}_{2} \mathrm{OC}_{6} \mathrm{H}_{4} \mathrm{CH}_{3}\right)$ & 0.2 & 93.3 & 0.7 & 65.0 \\
\hline 3 & $\left(\mathrm{C}_{6} \mathrm{H}_{5}\right)_{2} \mathrm{Bi}\left(\mathrm{OOC} \cdot \mathrm{CH}_{2} \mathrm{OC}_{6} \mathrm{H}_{4} \mathrm{Cl}\right)$ & 0.2 & 93.3 & 0.7 & 65.0 \\
\hline 4 & $\left(\mathrm{C}_{6} \mathrm{~F}_{5}\right)_{2} \mathrm{Bi}\left(\mathrm{OOC} \mathrm{CH}_{2} \mathrm{OC}_{6} \mathrm{H}_{5}\right)$ & 0.5 & 83.3 & 0.4 & 80.0 \\
\hline 5 & $\left(\mathrm{C}_{6} \mathrm{~F}_{5}\right)_{2} \mathrm{Bi}\left(\mathrm{OOC} \mathrm{CH}_{2} \mathrm{OC}_{6} \mathrm{H}_{4} \cdot \mathrm{CH}_{3}\right)$ & 0.2 & 93.3 & 0.7 & 65.0 \\
\hline 6 & $\left(\mathrm{C}_{6} \mathrm{~F}_{5}\right)_{2} \mathrm{Bi}\left(\mathrm{OOC} \mathrm{CH}_{2} \mathrm{OC}_{6} \mathrm{H}_{4} \mathrm{Cl}\right)$ & 0.2 & 93.3 & 0.7 & 65.0 \\
\hline 7 & $\left(p-\mathrm{FC}_{6} \mathrm{H}_{4}\right)_{2} \mathrm{Bi}\left(\mathrm{OOC} . \mathrm{CH}_{2} \mathrm{OC}_{6} \mathrm{H}_{5}\right)$ & 0.7 & 76.6 & 0.7 & 65.0 \\
\hline 8 & $\left(\mathrm{p}-\mathrm{FC}_{6} \mathrm{H}_{4}\right)_{2} \mathrm{Bi}\left(\mathrm{OOC} . \mathrm{CH}_{2} \mathrm{OC}_{6} \mathrm{H}_{4} \mathrm{CH}_{3}\right)$ & 0.8 & 73.3 & 0.8 & 60.0 \\
\hline 9 & 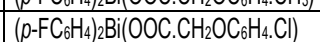 & 0.8 & 73.3 & 0.8 & 60.0 \\
\hline 10 & $\begin{array}{c}\text { Control } \\
\end{array}$ & 3.0 & - & 2.0 & - \\
\hline
\end{tabular}

On the basis of IR, NMR and UV spectral analysis data, it may tentatively concluded that aryloxyacetate under the present study behaves as a monodentate ligand. Conductance measurement and molecular Wight data showed that these aryloxyacetates have monomeric nature and are non conducting in nature. The experimental data are thus consistent with three coordinate pyramidal structures.

\section{Antibacterial activity}

The organobismuth (III) aryloxyacetates were tested for antibacterial activity against three bacterial strains Pseudomonas aeruginosa, Staphylococcus aureus and Klebsiela pneumoniae using $10 \mu \mathrm{g} / \mathrm{ml}$ concentration of test compound. All the compounds show higher to moderate activity against the bacterial strains. It was found that compounds having fluoro and pentafluorophenyl ring are more effective because of their water and lipid solubility. The fluorine containing compounds may generally form complexes with metaloenzymes, particularly those which responsible in basic physiology such as cytochrome oxidase. These compounds may react with peptidoglycan layer of bacterial cell wall and damage it by penetrating in such a manner that the phenyl ring gets entered inside the cell by puncturing it followed by death of bacterial cell. Sometimes these compounds in low concentration may cause bacteriostatic condition by slow down the growth of bacteria. 


\section{Antifungal Activity}

The antifungal activity of organobismuth (III) compounds was tested against Aspergillus flavus and Aspergillus niger using $50 \mu \mathrm{g} / \mathrm{ml}$ concentration. The activity of these compounds was found variable at $50 \mu \mathrm{g} / \mathrm{ml}$ concentration against fungal strains. Presence of nitrogen, phenyl and pentafluorophenyl ring along with bismuth in +3 oxidation state are considered for fungal activity. The role of different aryloxyacetates as ligands was also commendable. These compounds generally damage the fungal strains by puncturing the cell wall similarly as in the case of bacteria. Water and lipid solubility of these compounds, due to presence of fluorine, also increases the activity due to presence of fluorine.

Application of research: Applicable for study of antimicrobial activity of Organobismuth compounds

\section{Research Category: Antibacterial activity}

Acknowledgement / Funding: Author thankful to Department of Chemistry, Mewar University, Chittorgarh, 312901, Rajasthan

\section{${ }^{*}$ Research Guide or Chairperson of research: Dr Ravi Kant}

University: Department of Chemistry, Mewar University, Chittorgarh, 312901, Rajasthan

Research project name or number: PhD Thesis

\section{Author Contributions: All author equally contributed}

Author statement: All authors read, reviewed, agree and approved the final manuscript

\section{Conflict of Interest: None declared}

Ethical approval: This article does not contain any studies with human participants or animals performed by any of the authors.

\section{References}

[1] Thayer J.S. (1974) J. Organometal. Chem., 76, 265.

[2] Doak G.O. and Freedman L.D. (1973) Wiley Interscience, New York, 1973.

[3] Christiansen W.G. (1925) Organic derivatives of antimony" Chem. Catalog. Co., New York, 101.

[4] Sijpesteya A.K., Luijten J.G.A. and Vander Kerk G.J.M. (1969) in B. C. Toregeson (Ed.), Academic Press, New York, 331.

[5] Bernes J.M. and Magos L. (1968) Organometal. Chem. Rev., 3, 137.

[6] Langer H. G., U.S. 3, 442, 922(C1. 260-429), 7:C07F, OIm A., A 61K) 06 May 1969, Appl.09April 1964, 4pp Chem. Abst., 72, 12880, 1970.

[7] Varsanyl D., Margot A. and Sohwinn F., S. African 7006908, 94 June 1971, Swiss Appl. 15, 234/69, 10 Oct., 1969 35pp, Chem. Abst., 76,141028, 1972.

[8] Norbury H., Advances Inorg, Chem. Radio Chemistry, Eds. H. J. Emeleus and A. G. Sharpe (1975) Academic Press, New York, , 17.

[9] Ham N. S. and Willis J. B. (1960) Spectrochim. Acta, 16, 393.

[10] Lieber E., Rao C.N.R. and Ramachandran J. (1959) Spectrochim. Acta, 13, 296.

[11] Mitchell P.C.H. and Williams R.J.P. (1960) J. Chem. Soc, 1912.

[12] Caldow G.L. and Thompson H.W. (1958) Spectrochim. Acta, 13, 212.

[13] Ham N.S. and Willis J. B. (1960) Spectrochim. Acta, 16, 289.

[14] Cummins R.A. and Dunn P. (1964) Aust. J. Chem, 17, 411.

[15] Sabatini A. and Bertini T. (1965) Inorg. Chem., 4, 959.

[16] Clark R.J.H. and Williams C.S. (1965) Spectrochim. Acta, 22, 1081.

[17] Bertazzi N., Alonzo G., Silvestru A. and Consiglio G. (1972) J. Organometal. Chem, 37, 281.

[18] Aynseley E. E., Greenwood N.N., Hunter G. and Sprague M.S. (1966) J. Chem. Soc, 1344.

[19] Thayer J.S. and West R. (1967) Academic Press, New York, 5, 169.
[20] Kant R., Amresh G., Chandrashekar K. and Anil K.K.S. (2008) Phosphorus, Sulfur and Silicon, 183, 1410-1419.

[21] Soni K.K., Kumar Alok and Kant R. (2015) Inter. Jour. of Chem. Resear, $7(1), 159-163$

[22] Soni K.K., Kumar Alok and Kant R. (2016) Inter. Jour. of Chem. Resear., 8(1), 168-172. 